Sharif University of Technology
Scientia Iranica
SCIENTIA
I RAN I CA
Transactions A: Civil Engineering
www.scientiairanica.com

\title{
Experimental study on behavior of soil-waste tire mixtures
}

\author{
M. Ehsani ${ }^{a, *}$, N. Shariatmadari ${ }^{a}$ and S.M. Mirhosseini ${ }^{\mathbf{b}}$ \\ a. School of Civil Engineering, Iran University of Science and Technology, Narmak, Tehran, P.O. Box 163-16765, Iran. \\ b. Department of Civil Engineering, Amirkabir University of Technology, No. 424, Hafez Ave., Tehran, P.O. Box 15875-4413, Iran.
}

Received 2 February 2015; received in revised form 26 October 2015; accepted 28 November 2015

\section{KEYWORDS \\ Soil-tire mixture; \\ Triaxial experiment; \\ Softening behavior; \\ Elastic properties; \\ Flexible layer.}

\begin{abstract}
Waste tires are extensively being used in civil engineering applications to improve flexibility and elastic properties of the base foundation material. Moreover, by using pure tires or soil-tire mixtures, rubber stockpiles, which cause lots of environmental contaminations, are being consumed. The objective of this research is to study the strength and elastic modulus variations of sands when combined with rubber materials in different sizes and percentages. Triaxial experiments were performed on various sand-rubber mixtures using static triaxial apparatus. Samples were constructed at the maximum dry density and optimum moisture content to consider engineering applications in dry regions. The results show that rubber content and rubber-sand particle size ratio, $D_{50, r} / D_{50, s}$, significantly affect the mixture behavior in the manner which increase in the former and decrease in the latter, leading to a more softening behavior. Furthermore, specific combination of sand and rubber, which may improve the elastic properties of the mixture, is proposed as a flexible base layer.

(C) 2017 Sharif University of Technology. All rights reserved.
\end{abstract}

\section{Introduction}

Large amounts of waste tires are produced annually which are either stockpiled in empty lots or dumped in landfills. Severe geo-environmental problems may occur in tire stockpiles, such as collection of rainwater, providing breeding ground for mosquitoes. On the other hand, stockpiled tires can be utilized in many civil engineering projects to improve mechanical properties of problematic soils.

Based on tire properties (e.g., unit weight, high hydraulic conductibility, and high elastic deformability), soil-tire mixtures have been used in civil engineering applications such as lightweight material in

\footnotetext{
*. Corresponding author. Tel.: +9821 77240399; Fax: +9821 r7240398

E-mail addresses: mahdi.ehsani@yahoo.com (M. Ehsani); shariatmadari@iust.ac.ir (N. Shariatmadari); smmirhos@aut.ac.ir (S.M. Mirhosseini)
}

retaining wall backfills [1-11], slope stabilizer, drainage system, landfill leachate collection material, highway crash barrier, sound barrier fill, pavement frost barrier, rubber asphalt pavement [8,12], fuel-supplement [10], reinforcement layer [8], and soil improvement material [13].

According to studies performed by various researchers, major parameters affecting soil-rubber mixtures are tire content and rubber-sand particle size ratio, $D_{50, r} / D_{50, s}$. Some ranges of $D_{r} / D_{s}$ have been reported in previous pieces of research such as $D_{r} / D_{s} \approx$ 0.25 [14], $D_{r} / D_{s} \approx 0.8-1.1[15,16], D_{r} / D_{s} \approx 4[17]$, $D_{r} / D_{s} \approx 5[18], D_{r} / D_{s} \approx 10[19,20], D_{r} / D_{s} \approx 20$ $[7,10,21], D_{r} / D_{s} \approx 100[6], D_{r} / D_{s}>>100[4,8,9]$.

Lee et al. [6] and Masad et al. [7] carried out triaxial tests on tire chips having particle sizes from 2 to $51 \mathrm{~mm}$. Yang et al. [21] investigated the shear strength of soil-rubber mixtures using direct shear and triaxial apparatus. Bergado et al. [22], Zornberg et al. [4], and Youwai and Bergado [20] also examined strength 
characteristics of mixtures of different shape and size and different tire contents by triaxial apparatus and concluded that maximum shear strength is obtained in the mixture having about $35 \%$ rubber by weight. Gotteland et al. [23] also reported 34\% rubber as the optimum value at the confining pressures under $100 \mathrm{kPa}$. Mixtures containing soil and rubber of 10 to $20 \mathrm{~mm}$ were experimented by triaxial tests by Rao and Dutta [24], and it was concluded that up to $20 \%$ of tire could be useful in highway construction. Rahman and Erlingsson [25], Pasten et al. [26], Perez et al. [27], and Wichtmann et al. [28] carried out various numerical analyses to evaluate stress-strain relationship of pure soils using finite element method and mathematical models.

In this research, authors tried to investigate static stress-strain behavior of soil-granular tire mixtures having various rubber contents and rubber-soil particle size ratios. The experimental program involves static triaxial tests on mixtures with tire content ranging from $0 \%$ (pure sand) to $25 \%$ by sand volume. In addition to general behavior evaluation, the specific contribution of this research to the field of composite materials is introducing mixture which improves the flexibility of pavements and machine foundations. In other words, granular rubber amount and rubbersoil particle size ratio, which can change the mixture behavior from sand-like to rubber-like behavior and may cause the mixture to behave as almost linear elastic material, are identified.

\section{Materials and methods}

Two types of sandy soil, S161 and S131, with different grain size distributions with mean grain sizes of 0.26 and $0.79 \mathrm{~mm}$, were used in the laboratory experiments. Moreover, two different sizes of granular rubber having $G_{s}=1.1$ were used, R1 and R2, with the maximum grain size of $5 \mathrm{~mm}$ and $1 \mathrm{~mm}$, respectively. Particle size distribution diagrams of sands S161 and S131 and granular rubbers are shown in Figure 1.

\subsection{Soil-rubber mixture}

Mixture groups S161/R1, S131/R1, and S131/R2 were constructed using sand with $0 \%, 10 \%$, and $15 \%$ of granular rubber by sand volume. Special focus was directed on the mixture group S131/R2 by preparing a mixture having $25 \%$ rubber content by sand volume.

\subsection{Testing equipment}

Triaxial Digital Tritest machine manufactured by Engineering Laboratory Equipment (ELE) was employed for all triaxial experiments on samples with $70 \mathrm{~mm}$ diameter and $140 \mathrm{~mm}$ high. To record the load, deformation, and inner and outer specimen pressures, an automatic data logger system was used. Using Lin-

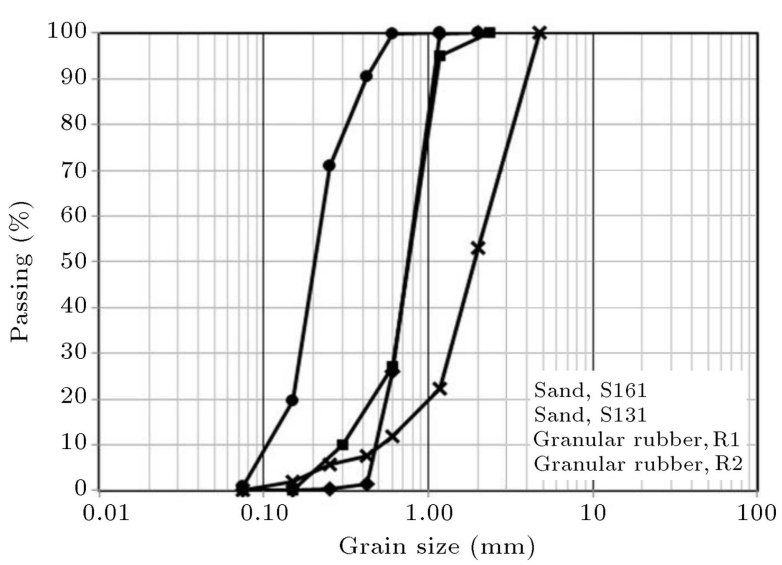

Figure 1. Particle-size distribution curves of sand and rubber.

ear Variable Differential Transformers (LVDTs) with a displacement range of about $40 \mathrm{~mm}$ and load cell with a capacity of $20 \mathrm{KN}$, axial strains and axial load were measured, respectively. Cell pressure and pore pressure were also recorded by using two pressure transducers connected to data logger system.

\subsection{Specimen preparation}

After mixing the appropriate amount of dry sand and rubber ranging from $0 \%$ (pure sand) to $25 \%$ by sand volume, water was added to the mixture and the mixed materials were then compacted in five layers providing almost maximum dry density at optimum water content. Table 1 shows compaction characteristics of mixtures derived from compaction experiments. Compaction was performed using a metal rod tamper and wet tamping procedure following the under-compaction method [17]. All specimens were prepared in the same manner and at about the same compaction energy.

\subsection{Testing program}

Nine wet specimens of two pure sands and seven sandrubber mixtures (rubber content in a range of $10-25 \%$ by sand volume) were investigated in static triaxial apparatus. After sample preparation, the triaxial cell was filled with water, and water pressure was then raised to about $30 \mathrm{kPa}$. Without conducting the saturation process, the cell water was pressurized to designated confining pressure. In the next step, consolidation was performed by applying the confining pressure to the sample and waiting for about 15 minutes while drainage valve was open. Finally, axial load was applied by the rate of approximately $0.5 \mathrm{~mm} / \mathrm{min}$ with closed drainage valve. The final stage was continued until the axial strain reached $20 \%$ or failure occurred. Table 2 demonstrates all designated experiments in three groups of different sand type and rubber material. Rubber percentage and ratio of mean grain size of sand versus rubber, $D_{50, r} / D_{50, s}$, are also illustrated as changing parameters of static tests. 
Table 1. Results of compaction tests.

\begin{tabular}{|c|c|c|c|c|c|c|}
\hline \multirow[t]{2}{*}{ No. } & \multirow[t]{2}{*}{ Mixture group } & \multirow[t]{2}{*}{ Compaction values } & \multicolumn{4}{|c|}{$\begin{array}{l}\text { Rubber content by } \\
\text { sand volume }(\%)\end{array}$} \\
\hline & & & $\mathbf{0}$ & 10 & 15 & 25 \\
\hline \multirow[t]{2}{*}{1} & $\mathrm{~S} 161 / \mathrm{R} 1$ & $\omega_{o p t}(\%)$ & 14 & 17.5 & 18 & \\
\hline & & $\gamma_{\max }\left(\mathrm{kN} / \mathrm{m}^{3}\right)$ & 16.5 & 16.1 & 15.9 & \\
\hline \multirow[t]{2}{*}{2} & $\mathrm{~S} 131 / \mathrm{R} 1$ & $\omega_{o p t}(\%)$ & 15.5 & 19 & 19.5 & \\
\hline & & $\gamma_{\max }\left(\mathrm{kN} / \mathrm{m}^{3}\right)$ & 15.6 & 15 & 14.8 & \\
\hline \multirow[t]{2}{*}{3} & $\mathrm{~S} 131 / \mathrm{R} 2$ & $\omega_{o p t}(\%)$ & 15.5 & 19 & 19.5 & 20.5 \\
\hline & & $\gamma_{\max }\left(\mathrm{kN} / \mathrm{m}^{3}\right)$ & 15.6 & 14 & 13.8 & 13 \\
\hline
\end{tabular}

Table 2. Scope of triaxial testing program.

\begin{tabular}{cccc}
\hline No. & Mixture group & $\boldsymbol{D}_{\mathbf{5 0}, \boldsymbol{r}} / \boldsymbol{D}_{\mathbf{5 0}, \boldsymbol{s}}$ & Rubber percentage \\
\hline 1 & $\mathrm{~S} 161 / \mathrm{R} 1$ & $12: 1$ & $0 \%, 10 \%, 15 \%$ \\
2 & $\mathrm{~S} 131 / \mathrm{R} 1$ & $3: 1$ & $0 \%, 10 \%, 15 \%$ \\
3 & $\mathrm{~S} 131 / \mathrm{R} 2$ & $1: 1.5$ & $0 \%, 10 \%, 15 \%, 25 \%$ \\
\hline
\end{tabular}

\section{Results and discussions}

\subsection{Effect of rubber inclusion on strength behavior of mixtures}

Figure 2(a), (b), and (c) show the influence of rubber percentage on strength properties of mixtures. Pure sand specimens exhibit well-defined peak shear strength as they are dense samples. According to diagrams, adding tire results in softer behavior and less peak deviatoric stress specifically as $D_{50, r} / D_{50, s}$ decreases (Figure 3). This trend was observed in all mixtures except for one mixture, S131/R2-85/15 in which peak deviatoric strength depends on strain level (Figures 2(c) and 3). Generally, contribution of granular rubber can significantly change the mixture behavior which is more severe as $D_{50, r} / D_{50, s}$ reaches unity. Based on stress-strain curves, all samples exhibit elastoplastic behavior except for mixture S131/R285/15 which behaves approximately bilinear elastic. In other words, mixture behavior can be represented by almost two lines with different slopes indicating two distinct values of mixture modulus in which the secondary modulus is dominant in all axial strains except for those less than about $1 \%$. Special considerations, including unloading the sample, are needed to investigate the elastic behavior of the mentioned mixture more precisely.

Another effect of increasing tire content on mixture behavior is initial modulus reduction. In other words, in the area of low strains, up to $5 \%$, mixtures of each group behave almost linearly, and increase in tire content results in less initial tangent modulus, as shown in Figure 4. This trend was observed in all samples.

\subsection{Effect of rubber-sand particle size ratio on strength behavior of mixtures}

Figure 5(a) and (b) demonstrate the effect of $D_{50, r} / D_{50, s}$ on stress-strain behavior of mixtures. As previously stated, strength of the mixtures decreases by reduction of $D_{50, r} / D_{50, s}$, when rubber content is constant. In other words, lower value of $D_{50, r} / D_{50, s}$ means more rubber to rubber interfaces, and mixture behavior is then controlled by rubber part of the mixture. All specimens experience the same trend except for S131/R2-85/15, as previously mentioned.

\subsection{Effect of rubber content on strength behavior of mixture $S 131 / R 2-85 / 15$}

Analysis of the presented results of nine static triaxial tests leads to some reasonable trends and one different result obtained for mixture S131/R2-85/15. Therefore, special focus was considered to investigate the effect of both $D_{50, r} / D_{50, s}$ and rubber content on stress-strain behavior of this mixture. It seems the parameter which plays a key role in the mentioned mixture behavior is $D_{50, r} / D_{50, s}$ which is less than unity. Moreover, $15 \%$ of rubber content is also required for the mixture to exhibit different strength characteristics, since mixture S131/R2-90/10 with $D_{50, r} / D_{50, s}<1$ and $10 \%$ of rubber content follows the general strength trend. Therefore, it can be concluded that in the mixtures having $D_{50, r} / D_{50, s}=1: 1.5$ or $0.67,15 \%$ of rubber content by sand volume is a threshold value beyond which sand-rubber mixture behavior transforms from elastoplastic behavior to approximately linear elastic behavior.

To better explore the minimum rubber con- 


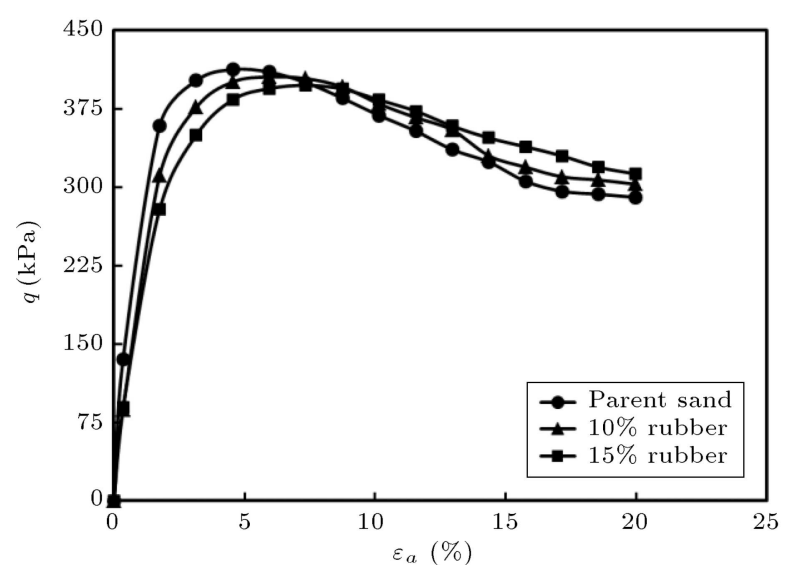

(a)



(b)



(a)

Figure 2. Rubber content influence on strength behavior of mixtures with $D_{50, r} / D_{50, s}:$ (a) $12: 1$, (b) $3: 1$, and (c) $1: 1.5$.

tent of mixture which results in approximately linear elastic behavior, another triaxial experiment with $D_{50, r} / D_{50, s}=0.67$ and $25 \%$ of rubber content by sand volume was considered to investigate the behavior of sand-rubber mixtures when rubber content exceeds $15 \%$, namely S131/R2-75/25. Figure 6 presents all stress-strain diagrams of the mixture group S131/R2. Based on Figure 6, it can be concluded that in mixtures having $D_{50, r} / D_{50, s}=0.67$ and rubber content less

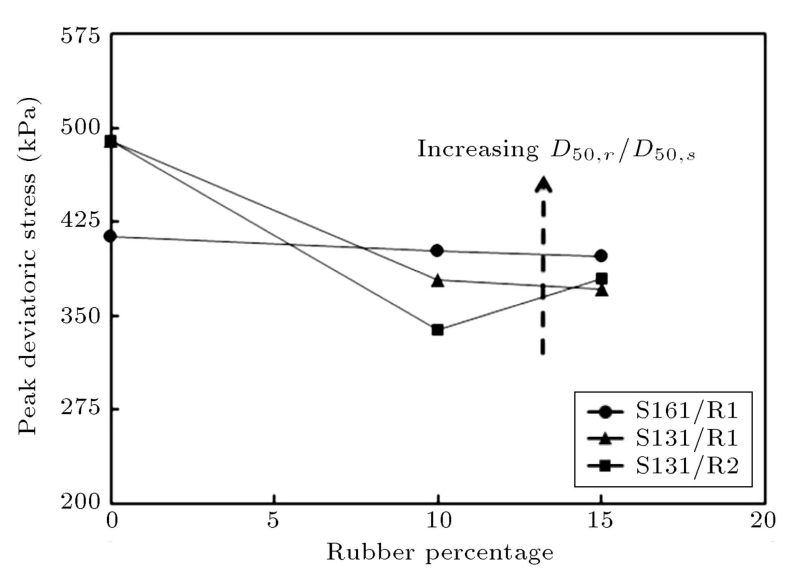

Figure 3. Effect of rubber content and $D_{50, r} / D_{50, s}$ on peak deviatoric stress of mixtures.



Figure 4. Effect of rubber content and $D_{50, r} / D_{50, s}$ on initial tangent modulus of mixtures.

than $15 \%$ by sand volume, strength behavior follows elastoplastic trend as expected; however, as rubber percentage exceeds $15 \%$ by sand volume, mixture behavior gradually transforms to almost linear elastic. As depicted, S131/R2-85/15 and S131/R2-75/25 diagrams can be represented by linear diagram beyond the axial strain of about $1 \%$ and $5 \%$, respectively. This trend was observed up to about $30 \%$ of axial strain.

\section{Conclusions}

In this study, static triaxial experiments were performed to explore the strength behavior of mixtures having different percentages of rubber and various rubber-sand particle size ratios. The main conclusions of this research are the following:

1. Increase in tire content leads to more softening behavior and strength reduction in mixture. As $D_{50, r} / D_{50, s}$ decreases, strength reduction occurs more severely;

2. Peak deviatoric stress and initial modulus of sandtire mixtures decrease as rubber content increases, 


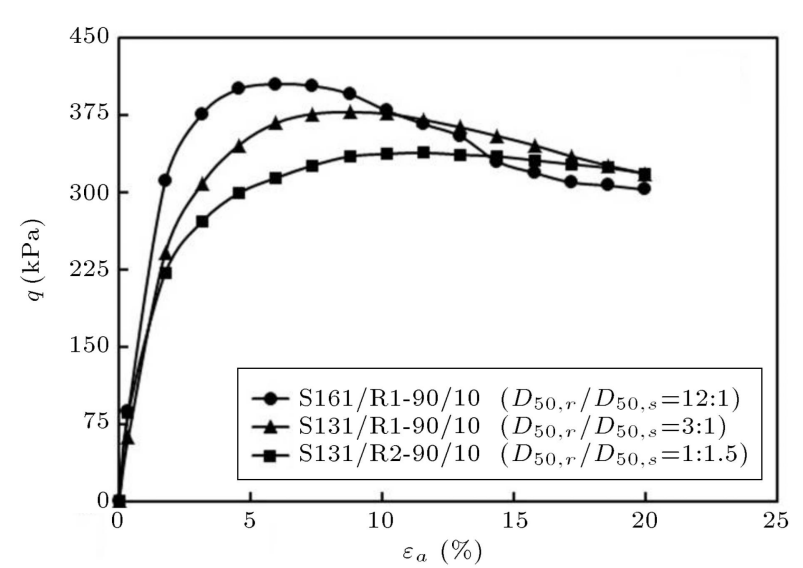

(a)



(b)

Figure 5. Effect of $D_{50, r} / D_{5} 0, s$ on strength behavior of mixtures having rubber content of (a) $10 \%$ and (b) $15 \%$ by sand volume.

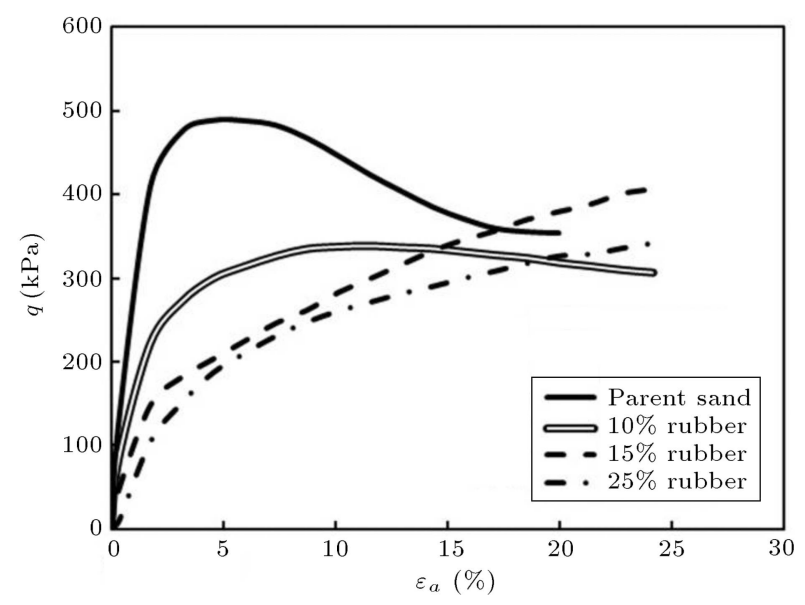

Figure 6. Rubber content influence on stress-strain behavior of mixture group S131/R2.

since rubber particles do not contribute significantly to the shear stiffness of the mixture;

3. Decrease in $D_{50, r} / D_{50, s}$ results in softer behavior and lower stiffness. As rubber-sand particle size ratio reduces, more rubber to rubber interactions occur, and rubber-like behavior then becomes more dominant;

4. All mixture groups exhibited approximately the same stress-strain trend except for mixtures of group S131/R2 containing rubber content of at least $15 \%$ by sand volume, S131/R2-85/15 and $\mathrm{S} 131 / \mathrm{R} 2-75 / 25$. The two mentioned mixtures having $D_{50, r} / D_{50, s}=0.67$ and rubber percentage of $15 \%$ and $25 \%$ by sand volume, behave differently, almost elastically, as results indicate. Mixtures of this group containing rubber content less than $15 \%$ demonstrate the general elastoplastic trend of other mixture groups; therefore, it can be inferred that at least $15 \%$ of rubber content by sand volume is needed to transform the behavior of mixture group S131/R2 from elastoplastic to approximately linear elastic;

5. Based on static test results, when rubber percentage of mixture group S131/R2 having $D_{50, r} / D_{50, s}=0.67$ exceeds $15 \%$ by sand volume, mixture flexibility is significantly improved. Hence, the mentioned combination of sand and tire can be used as machine foundation layer and flexible pavements;

6. Results of this study could be enriched by extra experiments to investigate behavior of mixtures having wider ranges of $D_{50, r} / D_{50, s}$ and rubber content percentages. Moreover, more laboratory experiments can be performed to study the effect of coefficient of uniformity, confining pressure, and moisture content on stress-strain characteristics of sand-tire mixtures.

\section{Acknowledgment}

The authors gratefully express their appreciation to the Geotechnical Research Center at Iran University of Science and Technology.

\section{References}

1. Wu, J.Y. and Tsai, M. "Feasibility study of a soil-based rubberized CLSM", Journal of Waste Management, 29(2), pp. 636-642 (2009).

2. Kaneda, K., Hazarika, H. and Yamazaki, H. "The numerical simulation of earth pressure reduction using tire chips in backfill", Proceedings of the International Workshop on Scrap Tire Derived Geomaterials, Japan, pp. 245-251 (2007).

3. Humphrey, D. "Effectiveness of design guidelines for use of tire derived aggregate as lightweight embankment fill", Recycled Materials in Geotechnics, 127, pp. 61-74 (2004).

4. Zornberg, J., Carbal, A. and Viratjandr, C. "Behaviour of tire shred-sand mixtures", Canadian Geotechnical Journal, 41, pp. 227-241 (2004). 
5. Garga, V.K. and O'Shaughnessy, V. "Tire-reinforced earthfill. Part I: Construction of a test fill, performance, and retaining wall design", Canadian Geotechnical Journal, 37(1), pp. 75-96 (2000).

6. Lee, J.H., Salgado, R., Bernal, A. and Lovell, C.W. "Shredded tires and rubber-sand as lightweight backfill", Journal of Geotechnical and Geoenvironmental Engineering, 125(2), pp. 132-141 (1999).

7. Masad, E., Taha, R., Ho, C. and Papagiannakis, T. "Engineering properties of tire/soil mixtures as a lightweight fill material", Geotechnical Testing Journal, 19(3), pp. 297-304 (1996).

8. Foose, G.J., Benson, C.H. and Bosscher, P.J. "Sand reinforced with shredded waste tires", Journal of Geotechnical Engineering, 122(9), pp. 760-767 (1996).

9. Edil, T.B. and Bosscher, P.J. "Engineering properties of tire chips and soil mixtures", Geotechnical Testing Journal, 17(4), pp. 453-464 (1994).

10. Ahmed, I. and Lovell, C.W. "Rubber soils as lightweight geomaterials in lightweight artificial and waste materials for embankments over soft soils", Transportation Research Record 1422, National Academy Press, Washington, pp. 61-70 (1993).

11. Humphrey, D. and Manion, W. "Properties of tire chips for lightweight fill", Grouting, Soil Improvement and Geosynthetics, 2(30), pp. 1344-1355 (1992).

12. Ali, B. and Sadek, M. "Experimental analysis of the influence of crumb rubber addition on the shortterm aging of Syrian asphalt", Arabian Journal of Geosciences, 6(1), pp. 85-90 (2013).

13. Edincliler, A. and Ayhan, V. "Influence of tyre fiber inclusions on shear strength of sand", Geosynthetics International, 17(4), pp. 183-192 (2010).

14. Lee, J.S., Dodds, J. and Santamarina, J.C. "Behavior of rigid-soft particle mixtures", Journal of Materials in Civil Engineering, 19(2), pp. 179-184 (2007).

15. Pamukcu, S. and Akbulut, S. "Thermoelastic enhancement of damping of sand using synthetic ground rubber", Journal of Geotechnical and Geoenvironmental Engineering, 132(4), pp. 501-510 (2006).

16. Yanagida, T., Matchett, A.J. and Coulthard, J.M. "Damping and elastic properties of binary powder mixtures", Journal of Powder Technology, 127, pp. 107-115 (2002).

17. Feng, Z. and Sutter, K.G. "Dynamic properties of granulated rubber/sand mixtures", Geotechnical Testing Journal, 23(3), pp. 338-344 (2000).

18. Anastasiadis, A., Pitilakis, K. and Senetakis, K. "Dynamic shear modulus and damping ratio curves of sand/rubber mixtures", Proceedings of the Earthquake Geotechnical Engineering Satellite Conference, XVIIth International Conference on Soil Mechanics and Geotechnical Engineering, Alexandria, Egypt (2009).

19. Kim, H.K. and Santamarina, J.C. "Sand-rubber mixtures (large rubber chips)", Canadian Geotechnical Journal, 45, pp. 1457-1465 (2008).
20. Youwai, S. and Bergado, D.T. "Strength and deformation characteristics of shredded rubber tire-sand mixtures", Canadian Geotechnical Journal, 40(2), pp. 254-264 (2003).

21. Yang, S., Lohnes, R.A. and Kjartanson, B.H. "Mechanical properties of shredded tires", Geotechnical Testing Journal, 25(1), pp. 44-52 (2002).

22. Bergado, D.T., Youwai, S. and Rittirong, A. "Strength and deformation characteristics of flat and cubical rubber tyre chip-sand mixtures", Géotechnique, 55(8), pp. 603-606 (2005).

23. Gotteland, P., Lambert, S. and Balachowski, L. "Strength characteristics of tyre chips-sand mixtures", Studia Geotechnica et Mechanica, 27(1-2), pp. 55-66 (2005).

24. Rao, G.V. and Dutta, R.K. "Compressibility and strength behaviour of sand-tyre chip mixtures", Journal of Geotechnical and Geological Engineering, 24, pp. 711-724 (2006)

25. Rahman, M.S. and Erlingsson, S. "Permanent deformation models of unbound granular materials: a comparative study based on multi-stage repeated-load triaxial tests", Transportation Research Board 93rd Annual Meeting, Washington DC, USA, Report \#140870, pp. 1-19 (2014).

26. Pasten, C., Shin, H. and Santamarina, J.C. "Longterm foundation response to repetitive loading", Journal of Geotechnical and Geoenvironmental Engineering, 140(4), pp. 04013036-1-04013036-11 (2014).

27. Pérez, I., Medina, L. and Gallego, J. "Plastic deformation behaviour of pavement granular materials under low traffic loading", Journal of Granular Matter, 12(1), pp. 57-68 (2010).

28. Wichtmann, T., Rondón, H.A., Niemunis, A., Triantafyllidis, Th. and Lizcano, A. "Prediction of permanent deformations in pavements using a high-cycle accumulation model", Journal of Geotechnical and Geoenvironmental Engineering, 136(5), pp. 728-740 (2010).

\section{Biographies}

Mahdi Ehsani received his BS degree in Civil Engineering from University of Tehran in 2005, MS degree in Geotechnical Engineering from Sharif University of Technology in 2008, and PhD degree in Geotechnical Engineering from Iran University of Science and Technology in 2015.

Nader Shariatmadari obtained his BS and MS degrees in Civil Engineering from Iran University of Science and Technology in 1986 and 1989, respectively. Dr. Shariatmadari earned his $\mathrm{PhD}$ degree in Geotechnical Engineering from University of Ottawa, Canada in 1996. He is currently a Professor of Geotechnical Engineering and faculty member at Civil Engineering Department in Iran University of 
Science and Technology. His main research interests are focused on Geoenvironmental Engineering including waste management, electrokinetics, and landfill design.

Seyed Majdedin Mirhosseini earned his BS and MS degrees in Civil Engineering from University of Tehran in 1976 and 1977, respectively. He received his $\mathrm{PhD}$ degree in Geotechnical Engineering from Leeds University, UK, in 1988. He is currently Professor of Geotechnical Engineering and faculty member at Civil and Environmental Engineering Department in Amirkabir University of Technology. Dr. Mirhosseini's main research interests include studying the stressstrain behavior of granular soils under monotonic and cyclic loading conditions along with evaluation of the behavior of embankment and rockfill dams according to instrumentation records during and after construction. 